\title{
STUDY ON EMISSION CONTROL BY BLENDING ETHANOL WITH PETROL IN MULTI CYLINDER SERVICED ENGINE
}

\author{
Mohankumar.P1, Karthikeyan. $\mathbf{V}^{2}$, Visagavel.K ${ }^{3}$ \\ ${ }^{1} P G$ Scholar, Industrial Safety Engineering, Knowledge Institute of Technology, Tamilnadu, India \\ ${ }^{2}$ Assistant Professor, Mechanical Engineering, Knowledge Institute of Technology, Tamilnadu, India \\ ${ }^{3}$ Professor, Mechanical Engineering, Knowledge Institute of Technology, Tamilnadu, India
}

\begin{abstract}
The objective of the study is to determine the effect on emissions of multi cylinder internal combustion engines due to ethanol blending .The exhaust emissions of multi cylinder serviced engine were tested and evaluated by using blends containing $5 \%, 10 \%, 15 \%$ ethanol, the gasoline in multi cylinder engine could be replaced with higher blend. The results showed that there is substantial reduction in exhaust gases like, Carbon monoxide, nitrogen oxides and hydrocarbon. The complete combustion resulting from use of ethanol increases carbon dioxide emission.
\end{abstract}

Keywords: spark ignition engine, emission, ethanol.

\section{INTRODUCTION}

There are lots of gases like nitrogen oxides, carbon dioxide and carbon monoxide in the environment causing pollution and global warming which are emitted from vehicle exhaust .Alcohol based fuels are used as renewable source of fuel for internal combustion engines. Alcohol fuel cannot be extensively used because of limited technology to use these fuel and high economy of the fuel. Ethanol replaced Methly Tertiary Butly Ether due to ground water contamination that leaked in filling station. Ethanol is biodegradable and having high octane number .Ethanol blended with gasoline has good result on environmental issues of pollution than pure gasoline.

The percentages of ethanol blend in gasoline are different in different countries .In India we are using 5\%ethanol in gasoline. A mixture of E-20 is common in Thailand and E25 most commonly used in Brazil. The flexible fuel vehicle can take higher concentration of ethanol. The E-85 having high octane rating of 105 is used in America.

\subsection{Properties of Fuel}

The heating value $\left(\mathrm{q}_{\mathrm{c}}\right)$ of fuel is the heat moved out of a system during combustion when reactants and products are at same temperature at its states.

The fuels octane number is a measure of tendency of resistance towards self -ignition of air fuel mixture. Higher the octane number results in higher ratio of compression before explosion.

The heat of vaporization is a measure of heat essential to cause phase change from a liquid to a gas of a fuel. The lowering of temperature of air-fuel mixture is as the result of high octane number which remove energy from neighboring air while vaporizing .

\subsection{Ethanol Blends vs Gasoline}

The volumetric efficiency of ethanol is higher than gasoline which is indicted by high heat of vaporization, there by increasing the power output. Each ethanol addition accounts for 5 units increase in octane number.

\begin{tabular}{|l|l|l|}
\hline Property & \multicolumn{2}{|l|}{ Fuels } \\
\hline & Ethanol & Gasoline \\
\hline Molecular formula & $\mathrm{C}_{2} \mathrm{H}_{5} \mathrm{OH}$ & $\mathrm{C}_{7} \mathrm{H}_{17}$ \\
\hline Octane number & $106-110$ & $91-96$ \\
\hline Density $\left(\mathrm{g} / \mathrm{cm}^{3}\right)$ & 0.785 & $0.72-0.78$ \\
\hline Heat of vaporization $(\mathrm{KJ} / \mathrm{kg})$ & 840 & 305 \\
\hline Stoichiometric fuel/Air ratio & 0.1111 & 0.0685 \\
\hline Molecular weight $(\mathrm{kg} / \mathrm{kmol})$ & 46 & $100-110$ \\
\hline Lower heating value $(\mathrm{MJ} / \mathrm{kg})$ & 26.9 & 44 \\
\hline
\end{tabular}

According to some studies ethanol blending decrease brake specific fuel consumption, fuel conversion efficiency and increase brake power. Other studies shows that there is slight decrease in fuel economy.

\section{EMISSIONS}

Exhaust emission depend on fuel composition, operating condition, oxygen content, air/fuel equivalence ratio and chemical structure. These gases affect the environment and results in increased global warming, acid rain thereby affecting human health.

\subsection{Nitrogen Oxides}

Nitrogen oxides are formed during combustion by reacting with air in the atmosphere .Nitrogen oxides form ozone by reacting in atmosphere and causes photochemical smog. Ozone cause lung disorders and harms biological tissues. 


\subsection{Carbon Monoxide}

Carbon monoxide is a poisonous gas emitted from the engine, when operated with fuel rich equivalence ratio. Carbon monoxide is formed when there is insufficient oxygen in fuel to convert carbon into carbon dioxide.

\subsection{Carbon Dioxide}

Carbon dioxide emission has been drastically increasing because of increase in number of vehicle .carbon dioxide does not have direct impact on human health but it affects the environment and contribute to global warming.

\section{LITERATURE REVIEW}

Palmar et.al [1] used several blend rates of ethanol-gasoline fuels in tests. The octane number and engine power output is increased by $5 \%$ for $10 \%$ ethanol addition. Altun sehmus et.al[2] experimentally investigated the performance and exhaust emissions of multi cylinder engine with gasoline and gasoline blended with $5 \%$ and $10 \%$ of ethanol. The engine was tested by changing the engine speed. The result from the study indicates that brake specific fuel consumption is greater than before while brake thermal efficiency, emission of carbon monoxide and hydrocarbon decreased with ethanol unleaded gasoline blends. Bata et al. [3] considered different blend of ethanol-gasoline in engines and determined that the ethanol could lessen the emission of $\mathrm{CO}$ and UHC to some degree. The decrease of $\mathrm{CO}$ emission is caused by oxygenated and wide flammability characteristic of ethanol. Ceviz M.A et al. [4] examined the effects of using ethanol-gasoline blends on emissions in a spark-ignited engine as well as on cyclic variability. Results of this study showed that using ethanol-unleaded gasoline blends as a fuel declined the coefficient of variation in specified mean effective pressure, Hydrocarbon and Carbon monoxide emission concentrations, the carbon dioxide concentration is increased up to $10 \%$ ethanol in fuel blend. Instead, after this level there will be a reverse outcome which was observed on the parameters above-mentioned. The best results was observed in fuel blend of 10vol. \% ethanol .

From the above it can be concluded that without modifying the engine design, pollutant emission can be reduced by alcohol-gasoline blended fuels.

\section{EXPERIMENTAL SETUP}

The following setup used to identify the effect of ethanol blends on emissions of multi cylinder serviced engine.

\subsection{Test Engine Apparatus}

The test engine's technical details are tabulated below. The tests were performed on this engine. The engine connects to mechanical brake dynamometer which acts as an external load and reduce the engine power.

\begin{tabular}{|l|l|}
\hline Engine parameters & 4stroke \\
\hline Cycle & Spark \\
\hline Ignition & $84 \mathrm{~mm}$ \\
\hline Bore & $82 \mathrm{~mm}$ \\
\hline Stroke & 4 \\
\hline Number of cylinder & 16 \\
\hline Number of valve & $1,3,4,2$ \\
\hline Cylinder firing order & \\
\hline
\end{tabular}

The properties of ethanol used for blend

\begin{tabular}{|l|l|}
\hline Property & Ethanol \\
\hline Carbon $(\mathrm{wt} \%)$ & 52.2 \\
\hline Oxygen $(\mathrm{wt} \%)$ & 34.70 \\
\hline Hydrogen $(\mathrm{wt} \%)$ & 13.10 \\
\hline Heating value(MJ/kg) & 27 \\
\hline Density $\left(\mathrm{kg} / \mathrm{m}^{3}\right)$ & 789 \\
\hline
\end{tabular}

In the experiment the percentage of Carbon dioxide, Carbon monoxide and Hydrocarbon are measured in the exhaust gas using AVL Digas 444 exhaust gas analyzer. The sampling of exhaust gas is taken without catalytic converter. The readings are taken with load and without load with engine rpm as constant. The readings are plotted in the form of graph in Microsoft excel and emissions are evaluated.

\section{RESULTS}

Gasoline with 5\%, $10 \%$ and $15 \%$ ethanol blends are prepared. $\mathrm{CO}, \mathrm{HC}$, NO was plotted in parts per million and $\mathrm{CO}_{2}$ and oxygen were plotted on volume percentage basis. While using E10 blend there is a significant amount of decrease in carbon monoxide emission and the results between load and no load condition are plotted (Chart-1).

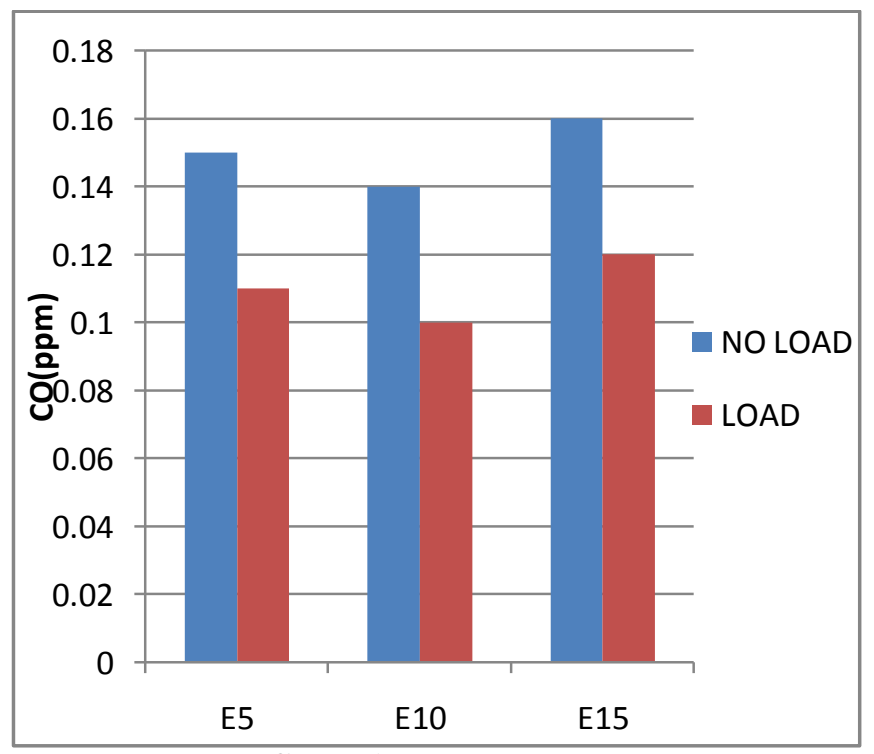

Chart-1: Co Emissions

The hydrocarbon emissions decreases when the engine load is minimum and it increase with increase in load the hydrocarbon emission is less in E10 blend compared to others (Chart-2). 


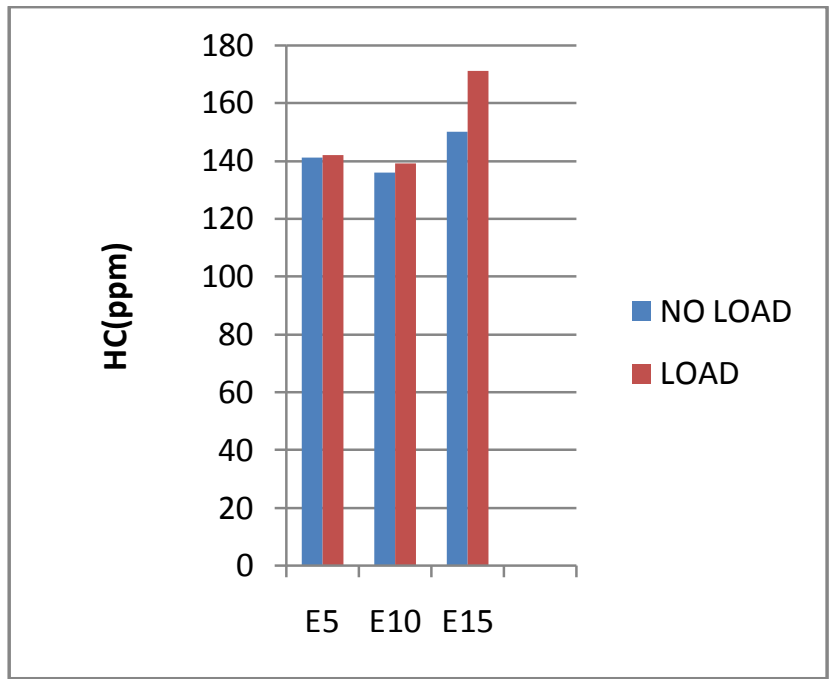

Chart-2: HC Emissions

Ethanol increases the carbon dioxide emission in engine exhaust because as the result of complete combustion and other incomplete products decrease (Chart-3).

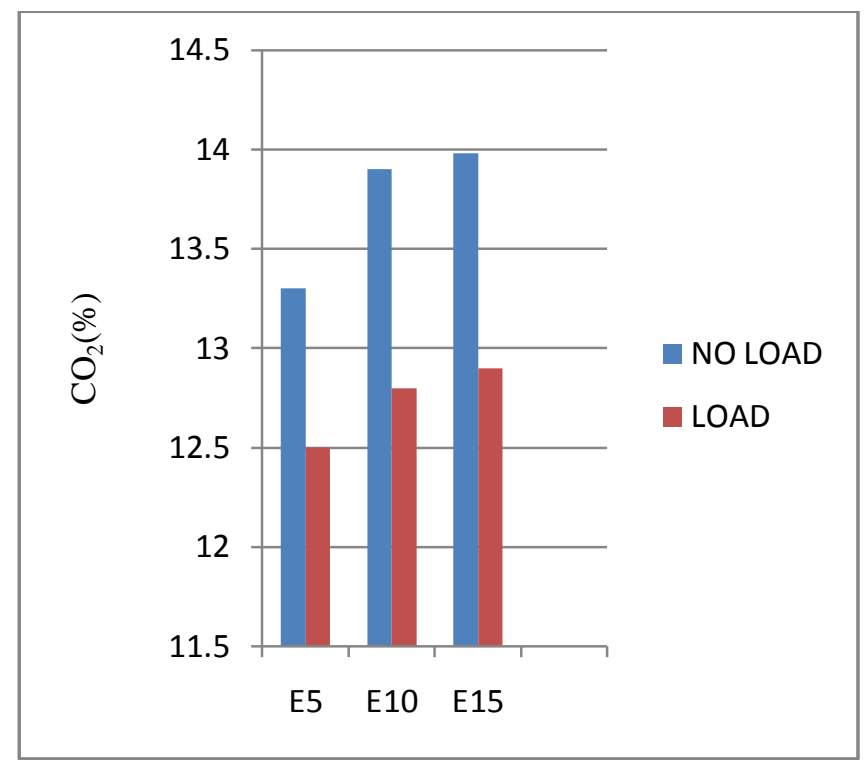

Chart-3: Carbondioxide Emissions

\section{DISCUSSIONS}

The results may have few weaknesses since it is a serviced engine and same gas tank which is used to supply the fuel to the engine, so there is a probability of some residue left in the tank. Therefore $10 \%$ ethanol blend showed desired result on emission of harm full pollutants.

\section{CONCLUSION}

$10 \%$ ethanol blends can be effectively used without modification in air/fuel system. CO,HC emissions can reduced by using different $\%$ of blends of ethanol in gasoline. Among which $10 \%$ is the best one to be used in multi cylinder engines without any alteration to reduce exhaust. A little attention has to be taken on pressure rise in the engine.

\section{REFERENCES}

[1] Palmer, F.H., 1986. Vehicle performance of gasoline containing oxygenates. International conference on petroleum based and automotive applications. Institution of Mechanical Engineers Conference Publications, MEP, London, UK, pp. 33-46.

[2] Altun Sehmus, Hakan F. Oztop, exhaust emissions of methanol and ethanol-Unleaded gasoline blends in a spark-ignition engine, applied energy, 86 (2009), pp. 630-639.

[3] Bata, R.M., Elord, A.C., Rice, R.W., 1989. Emissions from IC engines fueled with alcoholgasoline blends: a literature review. Transactions of the ASME 111, 424-431.

[4] Ceviz M.A, Yuksel F., effects of ethanol-unleaded gasoline blends on cyclic variability and emissions in an si engine, applied thermal engineering 25 (2005) 917-925.

[5] Ferguson, C. R. and Kirkpatrick, A. T., 2001, Internal Combustion Engines Applied

a. Thermosciences, John Wiley \& Sons, New York, pp. 1-28, 328.

[6] Baghdadi-Al, M., 2008, "Measurement and Prediction Study of the Effect of Ethanol

a. Blending on the Performance and Pollutants Emission of a Four-Stroke Spark Ignition Engine,"

b. IMechE, 222(D), pp. 859-873.

[7] Bayraktar, H., 2005, "Experimental and Theoretical Investigation of Using Gasoline-Ethanol

[8] Blends in Spark-Ignition Engines," Renewable Energy, 30, pp. 1733-1747. 